JIIP: JURNAL ILMIAH ILMU PEMERINTAHAN

Vol.6, No. 1, 2021

DOI: 10.14710/jiip.v6i1.9350

\title{
Analisis Optimalisasi Potensi Daerah untuk Meningkatkan \\ Pendapatan Asli Daerah Kota Malang
}

\author{
Reza Triarda ${ }^{1}$, Ratnaningsih Damayanti ${ }^{2}$ \\ ${ }^{1}$ Program Studi IImu Hubungan Internasional, Universitas Brawijaya \\ 2 Program Studi IImu Pemerintahan, Universitas Brawijaya
}

Dikirimkan: 10 November 2020 Direvisi: 23 Januari $2021 \quad$ Diterbitkan: 25 Maret 2021

\section{INTISARI}

Pendapatan Asli Daerah (PAD) seringkali dijadikan bahan komparasi antar kabupaten/kota di Indonesia. Tidak hanya besarannya saja, tetapi juga komposisinya terhadap jumlah pendapatan daerah selain dari dana perimbangan dan lain-lain pendapatan daerah yang sah menarik untuk dikaji. Umumnya, penerimaan PAD didominasi oleh pajak daerah. Sayangnya, jenis-jenis pajak daerah terlalu kaku sehingga menyulitkan bagi kabupaten/kota dalam berinovasi demi meningkatkan PAD. Untuk meningkatkan PAD lahkah pertama yang diperlukan adalah menganalisis potensi daerah masing-masing. Dengan mempergunakan dokumen-dokumen keluaran Pemerintah Kota Malang antara tahun 2012-2019 yang dianalisis secara kuantitatif, tulisan ini menemukan hasil bahwa perkembangan ekonomi telah merubah potensi daerah. Beberapa sektor pajak seperti BPHTB, PBB, dan PPJ tidak dapat lagi dijadikan sebagai sektor yang diandalkan apabila masih dikalkukasi dan dikelola dengan pemahaman lama. Terdapat faktor yang tidak dapat dikendalikan oleh pemerintah Kota Malang, seperti suku bunga bank, pertumbuhan ekonomi makro, nilai tukar rupiah terhada dolar, dan lain-lain yang juga berpengaruh pada realisasi pajak daerah. Perkembangan ekonomi Kota Malang telah menghasilkan primadona baru dalam pajak daerah, yaitu hotel dan restoran. Sayangnya Pemerintah Kota Malang masih terlalu berfokus pada BPHTB, PBB, dan PPJ sehingga belum mengoptimalkan potensi pajak hotel dan restoran.

KATA KUNCI

potensi daerah; pendapatan asli daerah; pajak daerah; Kota Malang

\section{Pendahuluan}

Pada era otonomi daerah seperti saat ini peran daerah dalam berkontribusi terhadap pendapatan negara merupakan faktor yang esensial. Pemerintah daerah bahkan berlomba-lomba untuk mendapatkan repatriasi dana yang besar dari pemerintah pusat. Mekanisme alokasi dan distribusi tak pelak menjadi mekanisme utama penentu repatriasi anggaran kepada Pemerintah Daerah. Masalahnya, tuntutan meningkatkan Pendapatan Asli Daerah (PAD) memiliki arti beda bagi masing-masing daerah. Bahkan seringkali motivasi dalam meningkatkan PAD tersebut tidak seiring

\footnotetext{
Korespodensi:
}

Jurusan Ilmu Politik, Pemerintahan dan Hubungan Internasional, Fakultas Ilmu Sosial dan Ilmu Politik, Universitas Brawijaya, Jalan Veteran, Malang , Jawa Timur , 65145.

Email: ratnaningsih@ub.ac.id 
sejalan dengan orientasi kesejahteraan dari pemerintah pusat. Pandaya (2016) menegaskan dalam tulisannya bahwa Pemerintah Daerah seringkali tidak memiliki motivasi untuk meningkatkan PAD karena mekanisme alokasi distrribusi dari pemerintah pusat yang dianggap tidak adil. Daerah yang memberikan kontribusi signifikan dalam pendapatan nasional seringkali harus berbagi dengan asas pemerataan dengan daerah yang berkontribusi minimal dalam pendapatan nasional. Daerah-daerah yang dalam kategorisasi "kering" seringkali bahkan melihat kondisi tersebut justru menguntungkan sehingga tidak memunculkan upaya yang signifikan untuk meningkatkan PAD mereka. Sebagaimana Pandaya (2016) sampaikan:

\footnotetext{
"Many regions resort to the laziest way of increasing their PAD raising their income from licensing and retribusi, fees local governments charge for the use of public facilities. In many cases, they mix up retribusi and tax, resulting in double taxation, especially in the mining and forestry sectors." [Banyak daerah menggunakan cara paling malas untuk meningkatkan PAD mereka dengan meningkatkan pendapatan dari perizinan dan retribusi, biaya yang dibebankan pemerintah daerah untuk penggunaan fasilitas publik. Dalam banyak kasus, mereka mencampur retribusi dan pajak, menghasilkan pajak berganda, terutama di sektor pertambangan dan kehutanan."]
}

Tulisan ini bertujuan untuk mengeksplorasi proses-proses yang dilakukan oleh pemerintah daerah untuk menjadi daerah yang mandiri secara keuangan. Ide dasar tulisan ini berangkat dari kondisi belanja daerah yang meningkat lebih besar dibandingkan dengan peningkatan pendapatan daerah, yang kemudian mengharuskan daerah untuk mengoptimalkan penggalian sumber-sumber pendapatan untuk meningkatkan PAD agar mampu menutupi biaya belanja daerah. Data dari Direktorat Jenderal Perimbangan Keuangan, Pemerintah Kabupaten/Kota maupun pemerintah provinsi secara agregat nasional mengalami peningkatan defisit. Perbandingan peningkatan pendapatan dan belanja pada APBD 2017 ke 2018 untuk Pemerintah Kabupaten/Kota adalah pendapatan naik 4,3\%, sedangkan belanja meningkat 4,5\%. Mengejar pertambahan nilai dalam PAD masih menjadi perhatian utama pemerintah daerah saat menyusun strategi-strategi jitu, dan bentuk-bentuk kebijakan.

Tulisan ini akan melengkapi penelitian-penelitian sebelumnya tentang keuangan daerah, khususnya dalam hal upaya pemerintah daerah meningkatkan kapasitas keuangannya untuk membiaya otonomi daerah. Tulisan ini tidak hanya akan menampilkan tren perkembangan pajak daerah dan retribusi daerah dari tahun-ke tahun saja namun tulisan ini secara teknis juga akan menampilkan data-data potensi daerah yang dapat dioptimalkan pada masa mendatang. Hasil penelitian ini akan menunjukkan jenis pajak atau retribusi daerah mana yang ke depannya akan meningkat penerimaannya. Dengan demikian, program intensifikasi dan ekstensifikasi yang diselenggarakan oleh pemerintah daerah dilakukan berdasarkan analisis yang lebih menyeluruh. 
Pada masa desentralisasi seperti saat ini, berbagai daerah di Indonesia sudah mengalami kemajuan pembangunan. Kemajuan pembangunan tersebut berdampak pada besarnya beban fiskal daerah. Tingkat perkembangan pembangunan yang cukup pesat di berbagai daerah ini sayangnya dibarengi dengan tingkat ketergantungan daerah dengan pusat yang cukup tinggi. Hal ini terjadi karena rendahnya Pendapatan Asli Daerah (PAD) dan dominannya transfer dari pemerintah pusat (Kuncoro, 2004). Selanjutnya Kuncoro (2004) menyebutkan penyebab utama dari ketergantungan fiskal di Indonesia adalah kurang berperannya BUMD sebagai sumber PAD, tingginya derajat sentralisasi dalam perpajakan, sedikitnya pajak daerah yang bisa diandalkan sebagai sumber penerimaan, adanya kekhawatiran bila daerah memiliki sumber keuangan tinggi akan menimbulkan separatisme dan disintegrasi, dan terdapatnya kelemahan dalam pemberian subsidi.

Desentralisasi fiskal di Indonesia diatur dalam UU No 33 tahun 2004. UndangUndang ini menyebutkan sumber pendapatan daerah terdiri atas Pendapatan Asli Daerah (PAD), Dana Perimbangan, dan lain-lain pendapatan yang sah. PAD bersumber dari Pajak Daerah, Retribusi Daerah, hasil pengelolaan kekayaan daerah yang dipisahkan, dan lain-lain PAD yang sah. Pada perkembangannya, setiap daerah di Indonesia cenderung berusaha untuk mengoptimalkan PAD. Usaha-usaha yang dilakukan oleh Pemerintah Daerah antara lain dengan melakukan intensifikasi dan ekstensifikasi pajak daerah. Intensifikasi pajak daerah adalah upaya pemerintah daerah untuk meningkatkan penerimaan pajak daerah dengan mengubah tarif pajak daerah dan peningkatan pengelolaan pajak daerah. Sedangkan ekstensifikasi pajak daerah adalah upaya peningkatan penerimaan pajak daerah melalui penciptaan sumber pajak baru.

Desentralisasi fiskal memberikan wewenang kepada pemerintah daerah untuk melakukan pembelanjaan dan memungut pajak. Secara umum, desentralisasi meliputi desentralisasi politik, desentralisasi administratif, dan desentralisasi fiskal. Desentralisasi fiskal merupakan komponen utama karena tidak terlepas dari isu kapasitas keuangan daerah, yaitu kemandirian daerah dalam menyelenggarakan pemerintahan diukur dari kemampuan menggali dan mengelola keuangannya (Yustika, 2008). Desentralisasi fiskal memungkinkan adanya model anggaran yang beradaptasi dengan masyarakat lokal (Musgrave, Richard A., Musgrave, 1989).

Strategi peningkatan PAD dapat berbeda antara daerah satu dengan daerah lain karena setiap daerah memiliki kondisi sosial ekonomi yang berbeda. Peningkatan PAD terjadi karena Pemerintah Daerah melaksanakan kajian optimalisasi pajak daerah yang menghasilkan objek pajak baru (ekstensifikasi pajak). Cara yang lain yang umum dilakukan adalah dengan intensifikasi pajak yakni mengoptimalisasi penerimaan pajak dari para wajib pajak. Daerah-daerah di Indonesia Timur memiliki strategi peningkatan PAD yang tidak jauh berbeda dengan daerah-daerah di Jawa. Di Kabupaten Enrekang yang terletak di Sulawesi Selatan, intensifikasi pajak dilakukan pada cakupan kelembagaan, tata laksana, dan personalia. Ekstensifikasi pajak dilakukan dengan 
menciptakan sumber pajak dan retribusi daerah baru dan membuka investasi (Safitra, 2019). Akan tetapi kurang optimalnya pemanfaatan potensi daerah menyebabkan penerimaan pajak juga tidak signifikan. Hal ini disebabkan karena manajemen pengumpulan pajak yang belum baik, data objek pajak yang tidak akurat, dan kurangnya kesadaran masyarakat untuk membayar pajak (Horota, Ida, \& Purba, 2014; Worumi, 2018).

Daerah di Pulau Sumatera, sebagai contoh adalah Kabupaten Rokan Hilir sebagai daerah penghasil tambang seharusnya merupakan daerah yang kaya namun masih mengalami kendala yang sama dengan optimalisasi potensi daerahnya untuk meningkatkan PAD. Hal ini terjadi karena dalam pengelolaan PAD masih belum memiliki sistem pengendalian yang dapat memastikan prosedur dan kebijakan yang telah dibuat ditaati oleh wajib pajak (Samad \& Iyan, 2013). Kejadian serupa juga terjadi di Kabupaten Sarmi di Papua. Lemahnya administrasi kelembagaan telah mengakibatkan tidak tercapainya target penerimaan pajak daerah selema beberapa tahun berturut-turut. Hal ini disebabkan payung hukum tentang penarikan pajak daerah di Kabupaten Sarmi belum diterapkan sepenuhnya (Worumi, 2018).

Pada dasarnya peningkatan penerimaan pajak daerah adalah dampak dari kegiatan ekonomi masyarakat setempat. Salah satu cara yang dipergunakan oleh pemerintah daerah yang dapat meningkatkan ekonomi yang berdampak ganda adalah mengembangkan pariwisata. Promosi daerah, khususnya pariwisata apabila dilakukan secara masif dapat mendatangkan wisatawan yang keberadaannya mampu memberikan dampak positif bagi perekonomian masyarakat (Liana, 2017). Peningkatan ekonomi masyarakat yang dibarengi dengan kesadaran membayar pajak akan dapat meningkatkan penerimaan pajak daerah karena aktivitas wisatawan diantaranya berhubungan dengan hotel, hiburan, dan restoran.

Jenis pajak daerah yang kaku membuat pemerintah daerah hanya mengimplementasikan jenis pajak sesuai dengan yang tertera dalam undang-undang. Ekstensifikasi pajak menjadi hal yang langka karena pemerintah daerah kurang inovatif. Hasilnya adalah pemerintah daerah hanya menjadi duplikat dari daerah lain padahal setiap daerah memiliki potensi yang berbeda. Dampaknya pada PAD adalah adanya jenis pajak daerah yang sangat tidak berpotensi namun terus dikembangkan karena sudah cetakan dari pemerintah pusat. Hal ini terjadi karena lemahnya administrasi dan kurangnya sanksi terhadap wajib pajak yang mangkir dari tagihan pajak (Wardhono, Indrawati, \& Qoriah, 2012).

Dari beberapa penjelasan di atas terdapat satu benang merah yang menarik untuk ditelusuri yakni terdapat fakta yang justru homogen dalam peningkatan PAD. Kondisi sosial yang berbeda-beda tidak menghasilkan variasi strategi dan inovasi dalam optimalisasi penerimaan PAD. Pada umumnya, PAD masih terus bertumpu pada intensifikasi dan ekstensifikasi pajak. Celakanya, ketika ketergantungan terhadap sektor 
pajak ini terus berlanjut maka pembangunan daerah juga berada dalam kondisi stagnan. Strategi dan inovasi yang memperkuat potensi daerah dalam sektor lain harus dioptimalisasi dalam rangka menyediakan multi channel dalam PAD.

Penelitian-penelitian di atas didasarkan pada kerangka desentralisasi dan otonomi daerah yang menekankan pada kemampuan daerah dalam membiayai diri sendiri, yaitu melalui realisasi pajak daerah dan retribusi daerah. Kebanyakan penelitian dianalisis berdasarkan analisis realisasi pencapaian target, hambatan dan kendala dalam pemungutan, dan strategi-strategi yang dilakukan oleh pemerintah daerah khususnya instansi terkait dalam mengoptimalkan pajak daerah dan retribusi daerah.

Kealpaan analisis penelitian-penelitian bidang ini adalah pada absennya konteks politik dalam kajian keuangan daerah. Otonomi daerah tidak hanya berhubungan dengan desentralisasi fiskal, tetapi juga desentralisasi politik, di mana keputusan keuangan didapatkan atas kesepakatan antara eksekutif dan legislatif daerah. Penetapan target penerimaan daerah, khususnya dalam pajak daerah dan retribusi daerah sangat berkaitan dengan keputusan legislatif daerah atau DPRD, yaitu pada persetujuan RPABD menjadi APBD. Dalam penelitian-penelitian sebelumnya, target dan realisasi pajak hanya dimaknai sebagai angka, padahal sejatinya angka-angka tersebut merupakan konsesi politik antara walikota dan jajarannya dengan DPRD.

Penelitian ini akan menggunakan data primer yaitu dengan melakukan interview kepada instansi-instansi terkait tentang strategi Optimalisasi Potensi Daerah dalam meningkatkan Pendapatan Asli Daerah (PAD) Kabupaten Malang dan Kota Malang serta nantinya akan mengalir untuk menemukan informan utamanya sehingga peneliti menggunakan purposefully (informan telah ditentukan) (J.W. Creswell, 1994) dan juga snowball sampling untuk menemukan informan kuncinya (www.straitstimes.com, 2016). Sedangkan untuk data sekunder peneliti akan menggunakan dokumen sekunder semisal diambil dari BPS dan/atau sumber yang lainnya.

Analisis akan menggunakan analisis isi untuk melihat bagaimana korelasi isi dari sumber satu dengan lainnya (Lofland, 2006). Data kualitatif juga perlu untuk dilakukan verifikasi data yaitu dengan menggunakan validitas internal dan konstruk serta realibiliasnya yaitu dengan menggunakan triangulasi sumber dan teknik (Creswell, 2014). Secara detail analisis data dan interpretasi dapat dijelaskan sebagai berikut. Analisis data menurut Gay adalah upaya penelitian kualitatif untuk meringkas data yang dikumpulkan secara akurat dan dapat diandalkan. Hal ini adalah penyajian temuan penelitian dengan cara yang lazim(Gay, L.R., Mills, G.E. and Airasian, 2006). Creswell memberikan tahapan dalam proses analisis data antara lain; 1). Mengolah data dan mempersiapkan data untuk dianalisis. Langkah ini termasuk transkripsi wawancara, men-scanning materi, mengetik data lapangan, memilih dan menyusun data berdasarkan sumber informasi; 2). Membaca keseluruhan data dengan merefleksikan makna secara keseluruhan dan memberikan catatan pinggir tentang gagasan umum yang diperoleh; 3). Menganalisis lebih detail dengan meng-coding data. 4).Menerapkan 
proses coding untuk mendeskripsikan setting, orang-orang, kategori-kategori dan tematema ini akan ditulis dalam narasi atau laporan kualitatif; dan 5). Menginterpretasikan data (Creswell, 2014).

\section{Optimalisasi Potensi Daerah untuk Meningkatkan PAD}

Kota Malang dikenal sebagai kota pelajar dikarenakan memiliki banyak fasilitas pendidikan. Berdasarkan data dari BPS Kota Malang, pada tahun 2019 jumlah sekolah setingkat TK berjumlah 463. Jumlah sekolah setingkat SD pada tahun 2019 berjumlah 343. Pada tahun 2019 jumlah sekolah setingkat SMP berjumlah 145 dan jumlah sekolah setingkat SMA berjumlah 30 sekolah.

Selain sekolah dasar dan sekolah menengah, di Kota Malang terdapat banyak perguruan tinggi baik negeri maupun swasta. Pemerintah Kota Malang dalam website resminya www.malangkota.go.id memberikan data 59 perguruan tinggi. Jumlah tersebut terdiri dari 5 politeknik, 9 akademi swasta, 4 institut swasta, 26 sekolah tinggi, 4 universitas negeri, dan 11 universitas swasta. Banyaknya jumlah perguruan tinggi ini artinya banyak pula jumlah mahasiswa di Kota Malang. Pada tahun 2020 terdapat sekitar 300.000 mahasiswa yang tinggal di Kota Malang (Kabul, 2020).

Jumlah penduduk Kota Malang pada tahun 2020 tercatat di BPS Kota Malang sebanyak 874.890 jiwa. Jumlah penduduk tersebut lebih banyak 0,48\% dari tahun 2019. Pertumbuhan penduduk ini salah satunya diakibatkan oleh migrasi penduduk masuk ke Kota Malang. Pada tahun 2019 terdapat 22.224 penduduk pendatang yang berpindah ke Kota Malang. Jumlah tersebut tidak termasuk dengan jumlah mahasiswa yang disebutkan di atas yang belum memiliki kartu domisili.

Kota Malang merupakan bagian dari Malang Raya (Koa Malang, Kota Batu, dan Kabupaten Malang). Iklim yang sejuk membuat daerah Malang Raya cocok dijadikan sebagai daerah bercocok tanaman, sayuran, dan bungan. Di Malang Raya juga banyak terdapat daerah wisata seperti Jatim Park 1,2,3, selecta, Desa Pujon Kidul, Museum Angkut, dan lain sebaginya. Walaupun bukan lokasi terdapatnya objek wisata, nama Malang sudah memiliki keunggulan tersendiri. Stasiun dan terminal bus besar yang terletak di Kota Malang memberikan Kota Malang keunggulan sebagai pintu masuk daripada Kota Batu dan Kabupaten Malang.

Selain untuk memberikan pelayanan kepada masyarakatnya sendiri Kota Malang juga menyediakan restoran dan hiburan untuk para pendatang. Pada tahun 2018 terdapat 4.824.407 wisatawan berkunjung ke Kota Malang. Pada tahun 2019 kunjungannya naik 8\% menjadi 5.186 .809 wisatawan domestik dan wisatawan mancanegara. Di Kota Malang, para pendatang ini disediakan hotel dan restoran. Sebagai fasilitas pendukung pariwisata, perkembangan hotel dan restoran di Kota Malang signifikan. Jumlah restoran pada tahun 2015 sebanyak 723 restoran dan jumlah 
ini naik lebih dari dua kali lipatnya selama 3 tahun. Pada tahun 2018 jumlah restoran di Kota Malang menjadi 1.444 (BPS Kota Malang, 2020). Banyaknya jumlah penduduk menyebabkan bisnis restoran atau penjualan makanan selalu ramai.

Untuk penginapan, di Kota Malang terdapat hotel berbintang, hotel non bintang, guest house, dan wisma pariwisata. Pada tahun 2019 terdapat 100 penginapan yang tersebar di 5 kecamatan di Kota Malang. Paling banyak adalah hotel non bintang yang berlokasi di Kecamatan Klojen. Hotel ini selain menyediakan kamar juga menyediakan meeting room sehingga tidak hanya menarik wisatawan, akan tetapi juga menarik para pegawai pemerintah atau swasta untuk menyelenggarakan rapat di Kota Malang.

Untuk memenuhi kebutuhan sehari-hari Kota Malang memiliki keunggulan memiliki lebih banyak pusat perbelanjaan modern daripada Kota Batu dan Kabupaten Malang. Diantaranya adalah Mall Olympic Garden (MOG), Malang City Point, Malang Towns Square, Transmart, Dinoyo Mall, dan lain sebagainya. Pusat perbelanjaan ini ramai dikunjungi warga baik Kota Malang maupun luar Kota Malang karena di kabupaten sekitar jumlah perbelanjaannya tidak sebanyak di Kota Malang. Di masingmasing pusat perbelanjaan modern ini juga terdapat bioskop dan wahana bermain untuk hiburan masyarakat.

Sama dengan kabupaten/kota lain, Pendapatan Pemerintah Daerah Kota Malang masih didominasi oleh dana perimbangan dari pemerintah pusat, yaitu dana bagi hasil pajak, dana bagi hasil bukan pajak, Dana Alokasi Umum, dan Dana Alokasi Khusus. Pada tahun 2012-2019 besarannya adalah 51\% sampai dengan 62\% dari total pendapatan yang diterima oleh Pemerintah Kota Malang antara tahun 2012 sampai dengan tahun 2019. Paling rendah adalah $51 \%$ terjadi pada tahun 2015 dan paling tinggi adalah $62 \%$ terjadi pada tahun 2016.

Pendapatan Asli Daerah (PAD) menempati urutan kedua dalam pendapatan Pemerintah Daerah Kota Malang. Komponen PAD Kota Malang yaitu pajak daerah, hasil retribusi daerah, hasil pengelolaan kekayaan daerah yang dipisahkan, dan lain-lain pendapatan asli daerah. Proporsi PAD terhadap total pendapatan Pemerintah Daerah Kota Malang antara tahun 2012-2019 adalah 17\%-30\%.

Jenis pendapatan terbesar ketiga dalam pendapatan Pemerintah Kota Malang adalah Lain-lain pendapatan daerah yang sah yang teridiri dari pendapatan hibah, dana bagi hasil pajak dari provinsi dan pemerintah daerah lainnya, dana penyesuaian dan otonomi daerah, dan bantuan keuangan dari Provinsi atau Pemerintah Daerah lainnya. Besaran jenis pendapatan ini antara 11\%-26\% antara tahun 2012-2019. Paling rendah yaitu tahun 2016 dan 2017 dengan 11\% dan paling tinggi adalah 26\% pada tahun 2015.

Di bawah ini merupakan diagram yang menunjukkan proporsi pendapatan daerah menurut jenisnya tahun 2012-2019. 


\section{Diagram 1 Perkembangan Proporsi Pendapatan Daerah Kota Malang} Menurut Jenis Tahun 2012-2019

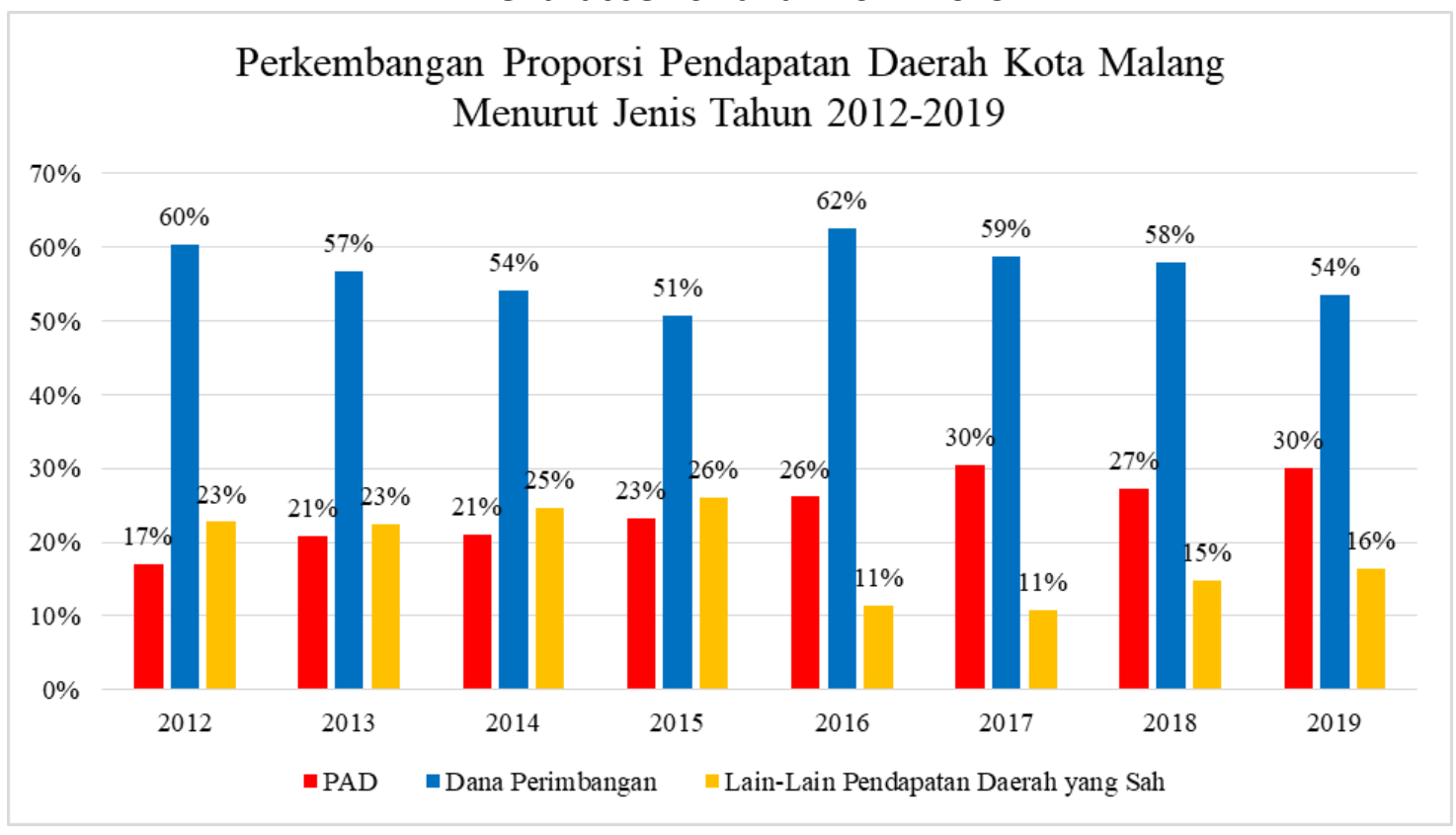

Sumber: BPS Kota Malang

Dari diagram batang di atas dapat dilihat bahwa pendapatan daerah dari dana perimbangan dan lain-lain pendapatan daerah yang sah mengalami kecenderungan yang fluktuatif antara tahun 2012-2019. Pendapatan Asli Daerah (PAD) adalah variable pendapatan daerah yang dapat dikontrol oleh pemerintah daerah memiliki kecenderungan proporsi yang naik antara tahun 2012-2019. Pada tahun 2012 proporsi PAD terhadap pendapatan daerah hanya 17\% namun tahun 2019 naik menjadi 30\%.

Sektor perpajakan secara umum masih menjadi penyokong utama dari Pendapatan Asli Daerah Kota Malang. Pajak daerah menempati porsi 68\% sampai dengan 75\% dari Pendapatan Asli Daerah antara tahun 2012 sampai dengan tahun 2019 (BPS Kota Malang, 2020). Selain dari pajak daerah, PAD disokong dari retribusi daerah, hasil pengelolaan kekayaan daerah yang dipisahkan, dan lain-lain pendapatan asli daerah.

Sejak tahun 2012 hingga 2018, sektor perpajakan selalu mampu untuk melampaui target dalam realisasi dan setiap tahunnya selalu bertambah. Sektor Perhotelan, restoran, hiburan, serta reklame tercatat menjadi kontributor terbesar pajak yang ada di Kota Malang dan performanya tidak pernah menurun. Akan tetapi pada tahun 2019 terjadi penurunan pada realisasi pajak, dalam kasus tersebut, ketiga sektor utama masih mampu berkotribusi secara signifikan. Penurunan justru ditimbulkan oleh sektor PPJ, Parkir, Air Tanah, dan BPHTB.

Di bawah ini merupakan grafik yang menunjukkan perkembangan jumlah pajak daerah Kota Malang. 


\section{Grafik 1 Penerimaan Pajak Daerah Kota Malang Tahun 2012-2019}

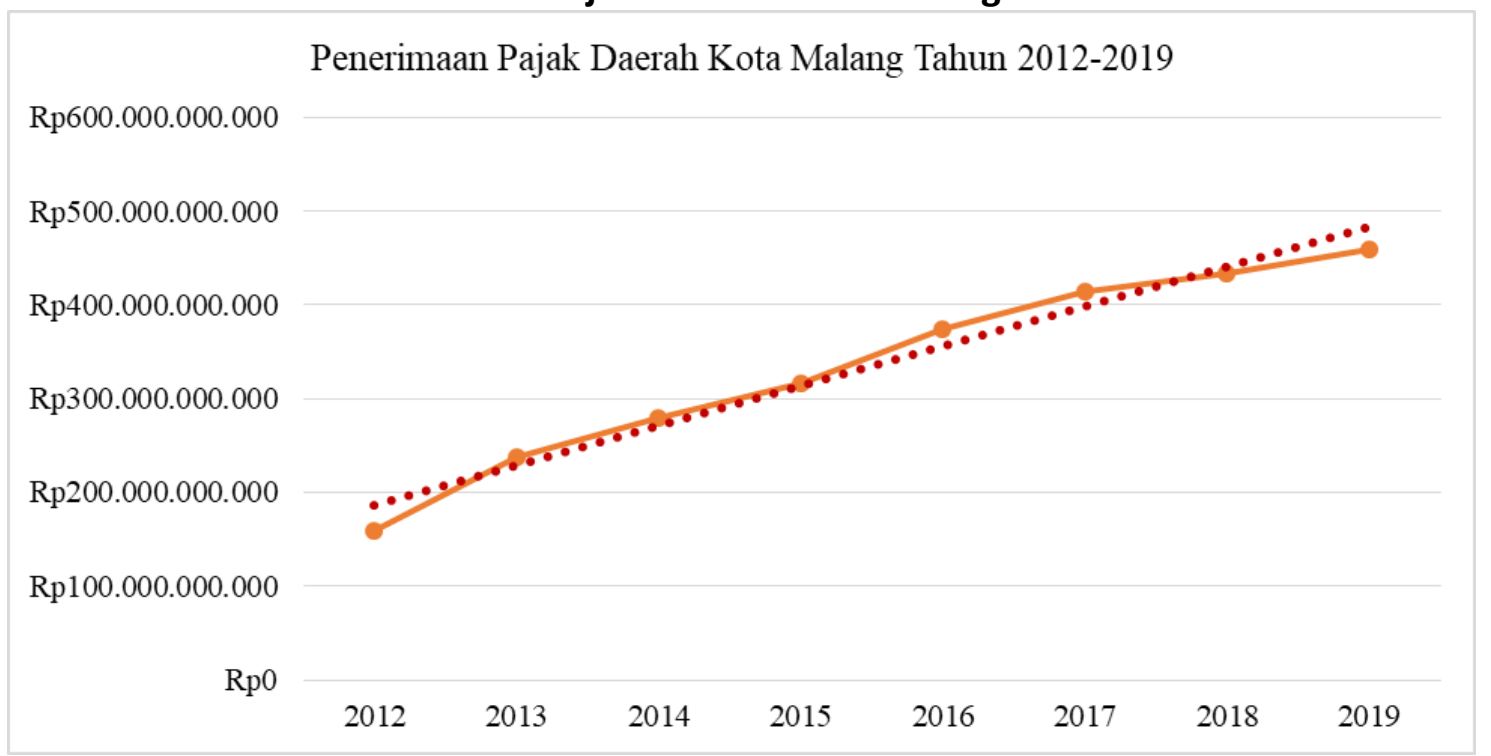

Sumber: Badan Pelayanan Pajak Daerah Kota Malang, 2020

Dari grafik di atas dapat dilihat bahwa jumlah pajak daerah Kota Malang selalu mengalami kenaikan dari tahun 2012-2019. Pada tahun 2015 Pemerintah Kota Malang mengeluarkan Peraturan Daerah Nomor 2 tahun 2015 tentang Perubahan atas Peraturan Daerah Kota Malang Nomor 16 Tahun 2010 tentang Pajak Daerah. Perubahan perda ini diantaranya berisi tentang penambahan objek pajak dan perubahan penentuan tarif pajak daerah. Adanya perda ini membuat realisasi penerimaan pajak daerah setelah tahun 2015 semakin meningkat.

Walaupun jumlah penerimaan pajak daerah setiap tahun selalu naik, namun pertumbuhan penerimaan pajak daerah Kota Malang mengalami tren penurunan. Tren penurunan ini dapat dilihat dalam grafik 2 di bawah ini.

\section{Grafik 2 Pertumbuhan Realisasi Pajak Daerah Tahun 2012-2019.}

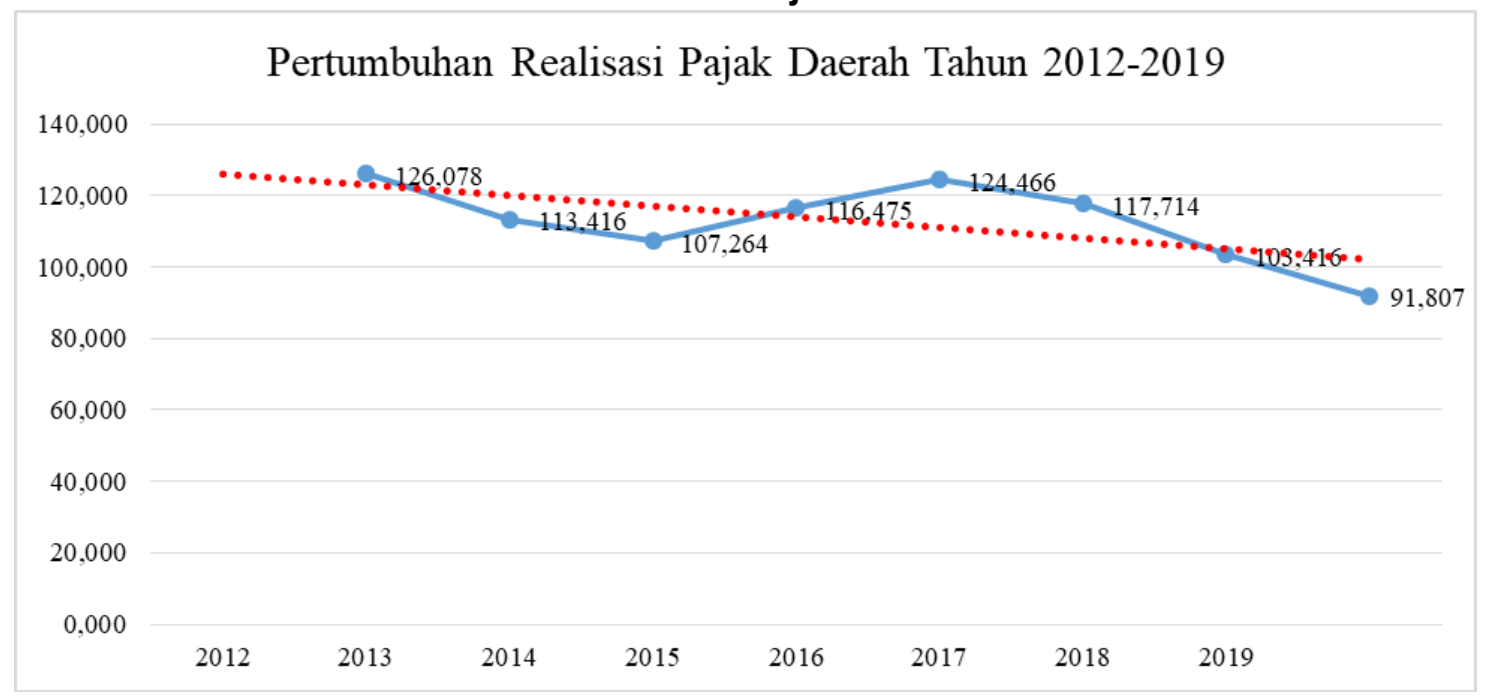

Sumber: Badan Pelayanan Pajak Daerah Kota Malang, 2020 
Pajak daerah pada tahun 2012 teralisasi 126,078\% kemudian perlahan-lahan turun sampai pada tahun 2019 realisasinya hanya 91,807\%. Penurunan realisasi penerimaan pajak daerah ini diakibatkan tidak terealisasinya target pajak penerangan jalan (80,35\%), parkir $(80,89 \%)$, air tanah $(97,38 \%)$, dan BPHTB $(74,17 \%)$.

Sektor perhotelan sebagai salah satu industri yang cukup lucrative di Kota Malang. Persebaran jumlah hotel cukup merata di beberapa kecamatan dengan aktivitas ekonomi yang tinggi. Pada tahun 2019 di Kota Malang terdapat 100 penginapan yang terdiri 29 hotel berbintang, 44 hotel non bintang, 10 guest house, dan 17 wisma pariwisata (BPS Kota Malang, 2020). Klojen menjadi kecamatan dengan jumlah hotel serta kamar terbanyak dengan rincian 20 hotel berbintang, 26 hotel non-bintang, 6 guest house, dan 11 wisma pariwisata. Kota Malang juga memiliki restoran dalam jumlah yang banyak, tercatat ada sekitar 1.444 restoran yang tersebar di 5 kecamatan dan Klojen menjadi lokasi konsentrasi restoran dengan jumlah 686 restoran.

Selain dikenal sebagai kota pelajar, Kota Malang juga dikenal sebagai daerah tujuan wisata bersama dengan Kabupaten Malang dan Kota Batu. Pada tahun 2019 terdapat 5.186.809 wisatawan yang terdiri dari 5.170.523 orang wisatawan domestik dan 16.286 orang wisatawan manca negara. Jumlah tersebut mengalami kenaikan sebesar $8 \%$ dari jumlah wisatawan pada tahun 2018. Dengan banyaknya kunjungan wisatawan dan jumlah penduduk baik asli maupun pendatang membuat bisnis perhotelan menjadi salah satu objek pajak yang dapat diandalkan oleh Pemerintah Kota Malang. Realisasi pajak hotel selalu mengalami kenaikan dan melebihi target selama tahun 2012-2019. Realisasi pajak hotel tercatat terendah sebesar109\% dan tertinggi sebesar $146,01 \%$. Proporsi penerimaan pajak hotel terhadap total pajak daerah sejak tahun 2012 perlahan-lahan mengalami kenaikan. Pada tahun 2012 pajak hotel hanya menempati 6\% dari total pajak daerah, namun pada tahun 2019 pajak hotel menempati $11 \%$ dari total pajak daerah.

Hotel dan restoran merupakan fasilitas pendukung pariwisata. Banyaknya jumlah restoran juga mempengaruhi penerimaan pajak restoran. Jumlah restoran di Kota Malang 5 tahun terakhir mengalami kenaikan yang signifikan. Jumlah restoran pada tahun 2015 sebanyak 723 restoran, sedangkan pada tahun 2018 dan 2019 sebanyak 1.444 restoran. Kenaikan jumlah restoran ini juga berpengaruh pada realisasi pajak restoran. Target pajak restoran selalu melebihi target. Realisasi terendah tercatat $107 \%$ pada tahun 2014, sedangkan realisasi tertinggi dicapai tahun 2015 dengan angka $137,21 \%$. Proporsi penerimaan pajak restoran terhadap total pajak daerah sejak tahun 2012 perlahan-lahan juga mengalami kenaikan. Pada tahun 2012 pajak restoran hanya 
menempati 13\% dari total pajak daerah, namun pada tahun 2019 pajak hotel menempati $18 \%$ dari total pajak daerah.

Jumlah penduduk dan kunjungan wisatawan yang banyak juga berpengaruh pada bisnis hiburan. Pajak tempat hiburan seperti bioskop, karaoke, billiard, panti pijat, dan lain-lain selalu naik dan melebihi target. Realisasi penerimaan tertinggi dicapai pada tahun 2012 dengan angka 158\% dan terendah pada tahun 2019 sebesar 112,31\%. Walaupun demikian, proporsi pajak hiburan terhadap pajak daerah hanya $2 \%-3 \%$ saja.

Pajak reklame adalah komponen pajak daerah yang proporsinya tidak stabil, yaitu antara 4\%-7\% dari total pajak daerah. Walaupun proporsinya tidak stabil, realisasi penerimaan pajak reklame selalu naik dan selalu mencapai target. Pada tahun 2019 realisasi pajak reklame mencapai $126,17 \%$ yang merupakan tertinggi antara tahun 2012 2019.

Pajak penerangan jalan (PPJ) pada tahun 2019 tercatat tidak mencapai target. Realisasi PPJ tahun 2019 hanya 80,35\%. Kejadian ini baru terjadi pada tahun 2019 karena selama tahun 2012-2018 realisasi PPJ selalu di atas 100\%. Pajak Penerangan Jalan adalah salah satu komponen utama yang menyumbang penerimaan pajak daerah Kota Malang. Pada tahun 2012, PPJ menyumbang $18 \%$ dari total pajak daerah, selanjutnya turun dan stabil pada angka 14\%. Tidak tercapainya target PPJ berpengaruh pada realisasi total penerimaan pajak daerah tahun 2019. Tahun 2019 realisasi pajak daerah Kota Malang hanya mencapai $91,81 \%$. Tidak tercapainya target ini salah satunya diakibatkan dari tidak adanya sinkronisasi data antara PLN dengan Badan Pelayanan Pajak Daerah (Sukarelawati, 2019).

Pajak parkir juga merupakan pajak daerah yang pada tahun 2019 realisasinya kurang dari target, yaitu hanya $80,89 \%$. Pajak parkir sebelumnya antara tahun 20122018 selalu mengalami kenaikan dan realisasinya tercapai. Namun pada tahun 2019, target pajak parkir mengalami kenaikan yang drastis dari tahun 2018, yaitu sebesar $55 \%$. Kenaikan target pajak parkir pada tahun 2019 sebesar 55\% inilah yang menyebabkan tidak terealisasinya target. Apabila dianalisis, kenaikan target pajak parkir dari tahun 2012 sampai tahun 2019 adalah sebesar 15\%-33\%. Walaupun realisasi jumlah penerimaan pajak parkir sudah melebihi jumlah target, namun terlalu tingginya kenaikan target penerimaan pajak parkir adalah bentuk kesalahan analisis potensi parkir di Kota Malang. Tidak terealisasinya pajak parkir juga merupakan bentuk dari kekeliruan manajemen pemungutan parkir di Kota Malang pada tahun 2019.

Pajak air tanah tahun 2019 realiasinya hanya 97,38\% dari target yang telah disusun. Sebelumnya yaitu pada tahun 2012-2018 pajak air tanah selalu memenuhi target dengan realisasi terendah 101,47\% pada tahun 2014 dan realisasi tertinggi pada tahun 2016 yaitu 134,96\%. Walaupun demikian, perolehan pajak air tanah tahun 2019 
telah melebihi perolehan pajak air tahan tahun 2018.Objek pajak air tanah antara lain usaha car wash, guest house, restoran, dan lain-lain yang mempergunakan air tanah. Pajak air tanah dalam pajak daerah adalah kontributor paling kecil, yaitu kurang dari $1 \%$ dari total penerimaan pajak daerah namun sektor yang paling stabil. Pemerintah Kota Malang tahun 2019 melaksanakan operasi gabungan, salah satunya mendatangi lokasi wajib pajak yang mangkir dari tagihan pajak air tanah. Alasan yang disampaikan kepada aparat pemerintah oleh wajib pajak adalah ketidaktahuan bahwa mereka harus membayar pajak air tanah (Ratri, 2019). Dengan demikian Pemerintah Kota Malang perlu lebih gencar lagi melakukan sosialisasi mengenai pajak daerah, khususnya pajak air tanah.

BPHTB atau Bea Perolehan Hak Atas Tanah dan Bangunan adalah penerimaan pajak yang keberadaannya tergantung dari jumlah transaksi atas tanah dan bangunan yang terjadi di Kota Malang. Tahun 2019 realisasi dari BPTHB adalah terendah sepanjang 2012-2019 yang hanya mencapai $74,17 \%$ dari target. Sebelumnya yaitu antara tahun 2012 perolehan pajak dari BPHTB selalu di atas target. Paling tinggi mencapai 141,47\% pada tahun 2012. Grafik perkembangan realisasi penerimaan BPHTB dapat dilihat di bawah ini.

\section{Grafik 3 Realisasi BPHTB Kota Malang Tahun 2012-2019}

\section{Realisasi BPHTB Tahun 2012-2019}

160,00

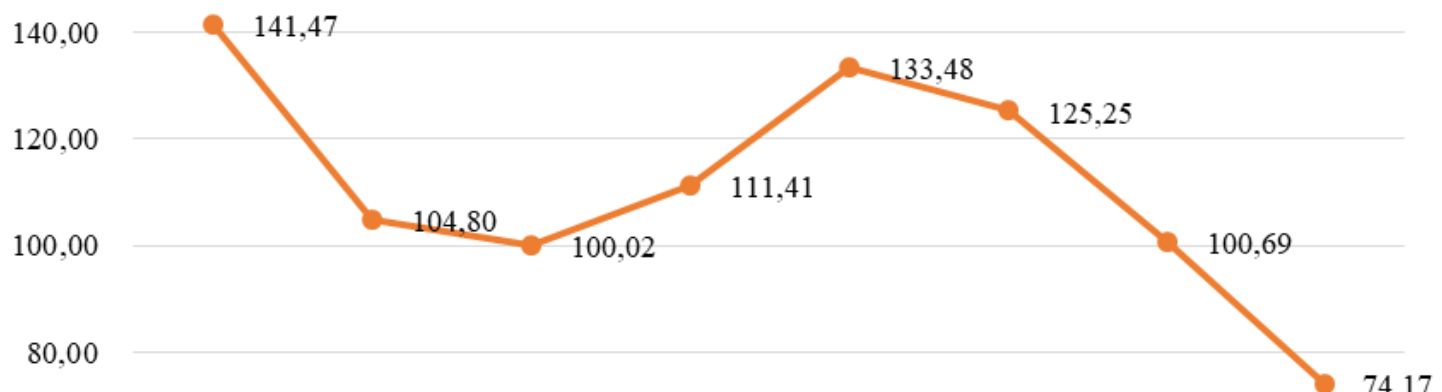

60,00

40,00

20,00

$\begin{array}{llllllll}2012 & 2013 & 2014 & 2015 & 2016 & 2017 & 2018 & 2019\end{array}$

Sumber: Badan Pelayanan Pajak Daerah Kota Malang, 2020 
Walaupun tren perkembangan kenaikan penerimaan BPHTB cenderung menurun, jumlah realisasi penerimaan BPHTB cenderung mengalami kenaikan. Diagram di bawah ini menunjukkan realisasi jumlah penerimaan BPHTB Tahun 2012-2019.

\section{Diagram 2 Realisasi Jumlah Penerimaan BPHTB Kota Malang Tahun 2012-2019}

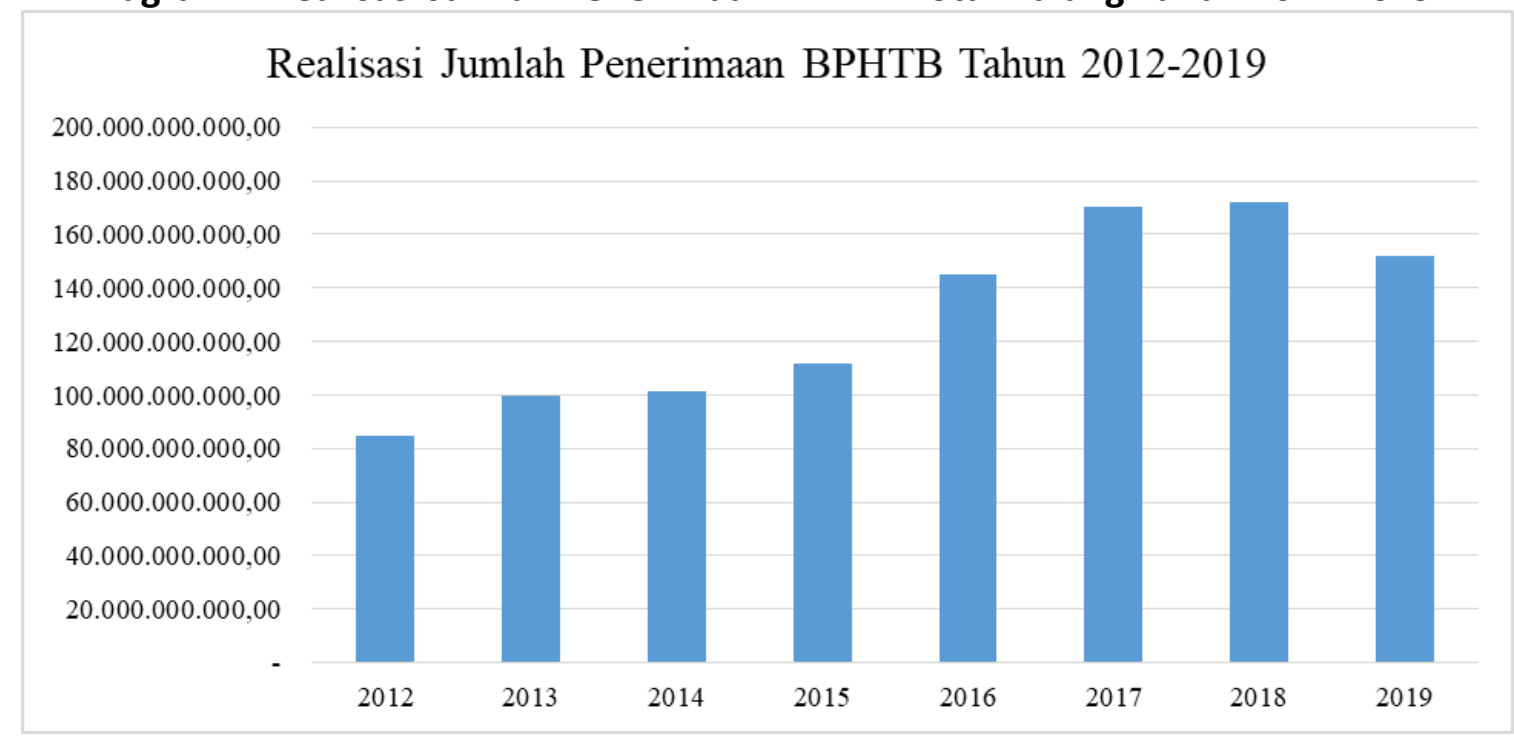

Sumber: Badan Pelayanan Pajak Daerah Kota Malang, 2020

Dari diagram di atas dapat dilihat bahwa jumlah penerimaan BPHTB mengalami tren kenaikan namun pada tahun 2019 realiasasi BPHTB turun drastis. Penurunan BPHTB ini dikarenakan jumlah transasksi tanah dan bangunan pada tahun 2019 turun drastis dari tahun 2019 (Ardiansyah, 2019).

BPHTB adalah komponen terbesar dalam penerimaan pajak daerah di Kota Malang. BPHTB memegang porsi 33\%-53\% dari total penerimaan pajak daerah. Porsi terendah terjadi tahun 2019 karena target tidak terealisasi, sedangkan porsi tertinggi terjadi pada tahun 2012 yaitu saat awal pengalihan BPHTB menjadi pajak daerah. Dengan tingginya porsi BPHTB terhadap pajak daerah maka keberadaan BPHTB diandalkan oleh pemerintah kota sebagai sumber pendapatan asli daerah yang utama. Apabila penerimaan BPHTB turun drastis, maka PAD juga akan turun drastis.

Komponen pajak daerah yang terakhir adalah PBB, yaitu Pajak Bumi dan Bangunan perdesaan dan perkotaan. Sejak pendaerahan PBB pertama kali tahun 2013, realisasi PBB selalu melebihi target, yaitu antara 100,02\% sampai dengan 109,75\% dari target yang ditetapkan. Diagram batang di bawah ini menunjukkan realisasi penerimaan PBB Kota Malang tahun 2013-2019. 


\section{Diagram 3 Realisasi Penerimaan PBB Kota Malang Tahun 2013-2019}

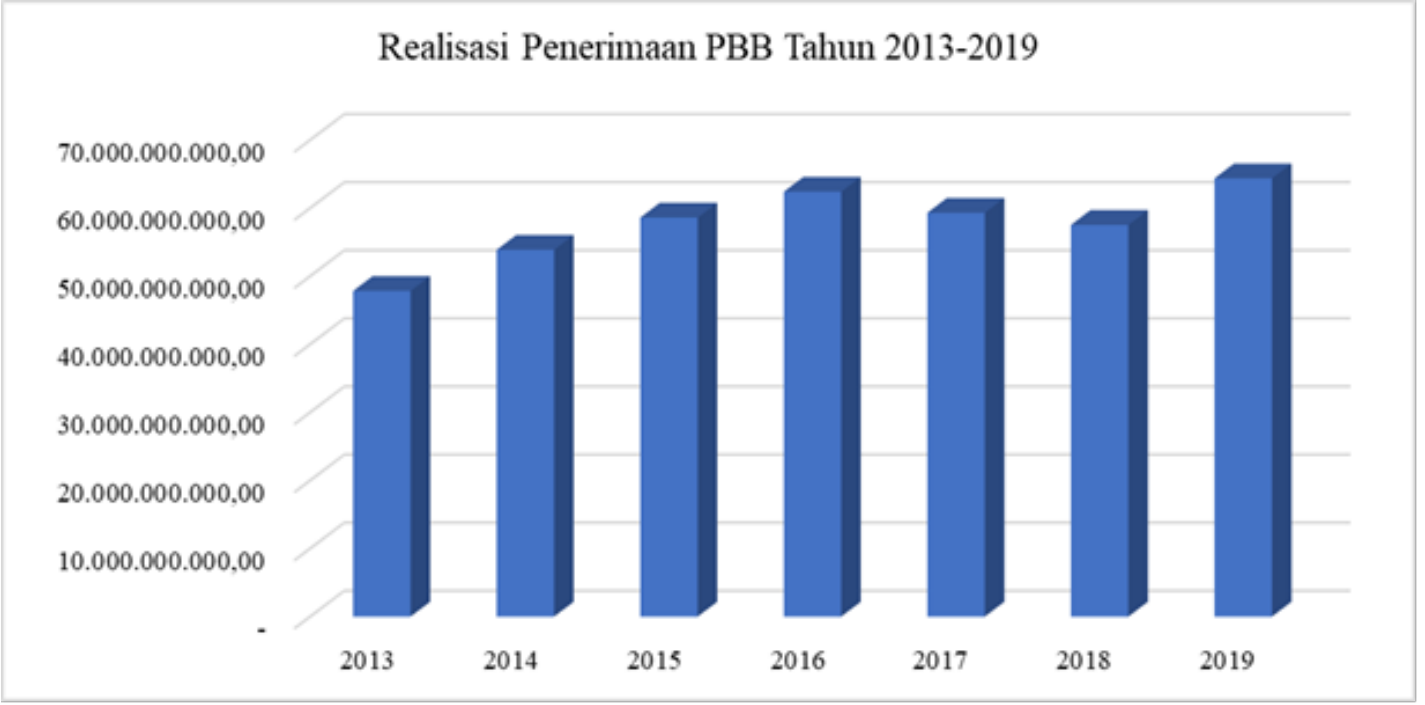

Sumber: Badan Pelayanan Pajak Daerah Kota Malang, 2020

Dari diagram di atas penerimaan PBB Kota Malang sejak tahun 2012 cenderung mengalami kenaikan. Selain itu, PBB juga merupakan komponen utama kedua dalam penerimaan pajak daerah Kota Malang. Proporsi PBB terhadap pajak daerah adalah antra 14\%-20\%. Proporsi tertinggi terjadi tahun 2013 dan proporsi terendah adalah 14\% terjadi pada 2017 dan 2019.

Dari uraian penerimaan pajak daerah di atas, terdapat 5 jenis pajak daerah yang mengalami perubahan tren realisasi selama kurun waktu 2012-2019. Perubahan ini dikarenakan perkembangan ekonomi dan tren pariwisata yang sedang berkembang. Kelima pajak terebut adalah pajak hotel, pajak restoran, pajak penerangan jalan, BPHTB, dan PBB. Kelima pajak ini adalah 5 komponen terbesar dalam penerimaan pajak daerah. Di bawah ini merupakan tabel perkembangan proporsi masing-masing pajak terhadap pajak daerah.

Tabel 1 Perkembangan Proporsi Penerimaan Pajak terhadap Pajak Daerah Kota Malang Tahun 2012-2013

\begin{tabular}{|l|l|r|r|r|r|r|r|r|r|l|}
\hline \multirow{2}{*}{ No } & \multirow{2}{*}{ Jenis Pajak } & \multicolumn{7}{|c|}{ proporsi terhadap pajak daerah } & \multirow{2}{*}{ Keterangan } \\
\cline { 2 - 8 } & & $\mathbf{2 0 1 2}$ & $\mathbf{2 0 1 3}$ & $\mathbf{2 0 1 4}$ & $\mathbf{2 0 1 5}$ & $\mathbf{2 0 1 6}$ & $\mathbf{2 0 1 7}$ & $\mathbf{2 0 1 8}$ & $\mathbf{2 0 1 9}$ & \\
\hline 1 & Hotel & $6 \%$ & $6 \%$ & $9 \%$ & $10 \%$ & $10 \%$ & $10 \%$ & $10 \%$ & $11 \%$ & tren naik \\
\hline 2 & Restoran & $13 \%$ & $11 \%$ & $11 \%$ & $12 \%$ & $13 \%$ & $13 \%$ & $12 \%$ & $18 \%$ & tren naik \\
\hline 3 & Hiburan & $2 \%$ & $2 \%$ & $2 \%$ & $2 \%$ & $2 \%$ & $2 \%$ & $2 \%$ & $3 \%$ & stabil \\
\hline 4 & Reklame & $6 \%$ & $4 \%$ & $7 \%$ & $6 \%$ & $6 \%$ & $5 \%$ & $6 \%$ & $5 \%$ & stabil \\
\hline 5 & PPJ & $18 \%$ & $14 \%$ & $14 \%$ & $14 \%$ & $13 \%$ & $13 \%$ & $14 \%$ & $13 \%$ & tren turun \\
\hline 6 & parkir & $1,13 \%$ & $0,81 \%$ & $0,95 \%$ & $1,16 \%$ & $1,30 \%$ & $1,27 \%$ & $1,16 \%$ & $1,49 \%$ & stabil \\
\hline 7 & Air Tanah & $0,32 \%$ & $0,29 \%$ & $0,29 \%$ & $0,25 \%$ & $0,22 \%$ & $0,19 \%$ & $0,25 \%$ & $0,64 \%$ & stabil \\
\hline 8 & BPHTB & $53 \%$ & $42 \%$ & $36 \%$ & $35 \%$ & $39 \%$ & $41 \%$ & $35 \%$ & $33 \%$ & tren turun \\
\hline 9 & PBB & & $20 \%$ & $19 \%$ & $19 \%$ & $17 \%$ & $14 \%$ & $19 \%$ & $14 \%$ & tren turun \\
\hline & JUMLAH & $100 \%$ & $100 \%$ & $100 \%$ & $100 \%$ & $100 \%$ & $100 \%$ & $100 \%$ & $100 \%$ & \\
\hline
\end{tabular}

Sumber: Badan Pelayanan Pajak Daerah Kota Malang, 2020 
Dari tabel di atas, terlihat pajak dengan warna hijau dan warna kuning. Pajak Warna hijau adalah pajak hotel dan pajak restoran. Pajak ini mengalami tren naik selama kurun waktu 8 tahun terakhir. Pajak dengan warna kuning adalah PJJ, BPHTB, dan PBB. Pajak ini mengalami tren penurunan selama 8 tahun terakhir. Sisanya pajak hiburan, rekrlame, parkir, dan air tanah adalah pajak yang kontribusinya relative stabil.

Berdasarkan lokasi wisata, Kota Malang bukanlah tujuan utama wisata namun memiliki banyak fasilitas pendukung pariwisata seperti penginapan dan restoran. Sektor ini sejak tahun 2012 mengalami tren kenaikan sejalan dengan peningkatan kunjungan wisatawan di kabupaten/kota sekitar dan kenaikan jumlah mahasiswa di Kota Malang. Untuk mengoptimalkan penerimaan pajak sektor ini, pemerintah Kota Malang perlu mempertimbangkan perkembangan penginapan dengan harga murah yang harganya lebih dapat dijangkau oleh wisatawan perkembangan guest house dan wisma pariwisata. Untuk mengoptimalkan penerimaan pajak sektor ini pemerintah perlu melakukan pendataan usaha penginapan dan pendataan restoran dari berbagai jenis, khususnya café yang dalam kurun waktu 2017-2019 berkembang cepat. Sektor hotel dan restoran bisa menjadi primadona baru pajak daerah asalkan sudah ada pendataan dan pengawasan yang tertib terhadap semua objek pajak hotel dan restoran.

Bisnis pariwisata Kota Malang selama kurun waktu 2017-2019 selalu meningkat. Peningkatan kunjungan wisatawan pada 2018 adalah 11\% sedangkan peningkatan kunjungan wisatawan pada 2019 adalah 8\%. Walaupun menjanjikan, sektor pariwisata rentan terhadap isu kamanan, bencana alam, dan isu kesehatan seperti pandemic covid19 yang terjadi pada tahun 2020. Pandemi covid19 telah melumpuhkan perekonomian, khususnya sektor pariwisata. Walaupun demikian, sektor pariwisata adalah sektor yang cepat pulih ketika situasi kembali normal.

Dalam hal fasilitas pendukung pariwisata ini, Pemerintah Kota Malang telah melakukan ekstensifikasi dan intensifikasi pajak. Hal ini dibuktikan dengan dikeluarkannya Peraturan Daerah Nomor 2 tahun 2015 tentang Perubahan Atas Peraturan Daerah Kota Malang Nomor 16 Tahun 2010 Tentang Pajak Daerah. Objek pajak hotel yang semula hanya ada 5 yaitu motel, losmen, rumah penginapan, rumah kos dengan jumlah kamar lebih dari sepuluh, dan kegiatan usaha lainnya yang sejenis bertambah menjadi 6 macam. Pemerintah Kota Malang menambahkan ruang apartemen yang berubah fungsi sebagai hotel maupun tempat kos sebagai objek pajak hotel. Penambahan objek pajak hotel ini sesuai dengan perkembangan ekonomi Kota Malang di mana mulai beroperasinya apartemen yang sebagian ruangannya disewakan untuk hotel maupun kos.

Usaha intensifikasi pajak diantaranya dilakukan dengan merubah tarif pajak restoran. Dalam perda Nomor 16 Tahun 2010 Tentang Pajak Daerah pasal 16 disebutkan bahwa tarif pajak restoran sebesar 5 persen apabila nilai penjualan restoran antara Rp 5.000.000 sampai dengan Rp 15.000 .000 per bulannya. Tarif 10 persen dikenakan bagi 
restoran yang nilai penjualannya di atas $\mathrm{Rp}$ 15.000.000 per bulan. Ketentuan tarif ini kemudian dirubah menjadi 10 persen per bulan dari nilai penjualan. Hal ini berarti semua jenis restoran yang penjualan per bulannya di atas Rp 5.000 .000 per bulan dikenai tarif pajak yang sama, yaitu 10 persen.

Selama kurun waktu 3 tahun, yaitu dari tahun 2015 sampai dengan 2018 jumlah restoran meningkat dua kali lipat. Namun berdasarkan data target pajak restoran, penetapan target pajak restoran sering kali disusun di bawah pencapaian pajak restoran tahun sebelumnya. Hal ini menandakan penetapan target penerimaan pajak yang disepakati antara walikota dengan DPRD adalah target minimalis. Tindakan ini dilakukan dimungkinkan demi tercapainya target kinerja dan stabilnya pertumbuhan penerimaan pajak restoran. Dengan demikian sejatinya intensifikasi pajak restoran tidak akan optimal apabila peran DPRD dalam mengawasi perencanaan anggaran daerah kurang optimal.

BPHTB, PBB, dan PPJ adalah 3 jenis pajak yang berkontribusi terbesar dalam penerimaan pajak daerah namun realisasinya kontribusinya dalam 8 tahun terakhir menurun. Besarnya penerimaan BPHTB tergantung banyaknya transaksi properti, sedangkan transaksi properti tergantung pertumbuhan ekonomi, suku bunga bank, dan faktor makro lain yg tidak dikendalikan pemerintah kota. Dalam kenyataannya, besarnya BPHTB lebih dipengaruhi oleh faktor eksternal (di luar kendali pemerintah kota). Untuk dapat mengoptimalkan kembali BPHTB, Pemerintah Kota perlu melakukan analisis pasar yang lebih jeli sebelum menentukan target. Sebagai contoh adalah analisis peluang pengembangan properti baru, penjualan properti bekas, kebijakan $\mathrm{Bl}$ yang mempengaruhi suku bunga bank umum, inflasi, bahkan potensi krisis ekonomi baik nasional maupun internasional. Hal ini karena BPHTB dipengaruhi oleh bisnis properti, yang mana bisnis properti ini rentan terhadap imbas krisis ekonomi dari luar negeri.

Walaupun realisasi PBB selalu melebihi target, proporsi penerimaan PBB terhadap pajak derah mengalami tren penurunan. Strategi Pemerintah Kota Malang dalam optimalisasi PBB dilakukan melalui beberapa hal. Pertama, sosialisasi melalui berbagai media dank e sekolah-sekolah di Kota Malang. Kedua, melakukan kerja sama dengan Polres Malang Kota, Kejaksaan Negeri Malang, Tim Auditor BPKP Perwakilan Jawa Timur, Kerjasama dengan Media Massa. Ketiga, Membentuk Satuan Petugas (Satgas) Peningkatan Pajak Daerah dan menggalakan Operasi Gabungan (OPGAB) Sadar Pajak bersama Badan Narkotika Nasional (BNN) Kota Malang, Kejaksaan Negeri, Polresta Malang, TNI, Satpol PP, Bagian Hukum dan media Massa. Keempat, melakukan pemetaan yang biasa dikenal dengan sebutan Cleansing dan Sensus. Kelima, melaksanakan Sunset Policy, yaitu penghapusan sanksi administrasi atau denda atas keterlambatan pelunasan PBB yang belum terbayar dalam rentang waktu antara tahun 1994 sampai dengan tahun 2012. Keenam, mengadakan mobil tax keliling multifungsi (Romi A.S \& Larasati, 2018). 
Yang dilupakan oleh Pemerintah Kota Malang dalam menetapkan PBB adalah, keluarnya Surat Pemeritahuan Pajak Terutang (SPPT) PBB merupakan ujung dari proses panjang administrasi surat tanah. Di antara persyaratan pengurusan SPPT PBB adalah Ijin Mendirikan Bangunan (IMB) dan sertifikat kemilikan tanah. Apabila kedua surat tersebut proses memperolehnya panjang, maka Pemerintah Kota Malang tidak akan optimal dalam melakukan penambahan wajib pajak baru PBB. Walikota Malang bahkan mengakui bahwa 95 persen bangunan di Kampus belum memiliki IMB. Menurutnya hal ini kesalahan berasal dari peraturan daerahnya (Malangtimes, 2020). Dengan demikian perlu dilakukan penyederhanaan proses administrasi kedua surat tersebut.

Strategi yang dapat dilakukan oleh Pemerintah Kota Malang untuk mengoptimalkan $\mathrm{PBB}$ selain mempermudah proses penerbitan persyaratan pembuatan SPPT PBB adalah melalui intensifikasi PBB. Intensifikasi PBB dapat dilakukan dengan beberapa cara. Pertama adalah revaluasi nilai tanah untuk menentukan NJOP baru atau menaikkan NJOP. Harga tanah di dekat pusat keramaian biasanya akan cepat mengalami kenaikan harga, oleh karena itu NJOP juga harus mengikuti naiknya harga tanah. Kedua, dengan melakukan perbaikan atau pelebaran jalan. Hal ini dilakukan untuk menaikkan status tanah sehingga NJOP juga akan naik. Ketiga, optimalisasi penerimaan PBB melalui kemudahan pembayaran PBB dengan kerja sama dengan pihak ketiga seperti perbankan, retail, kantor pos dan lain sebagainya. Dengan kemudahan sistem pembayaran maka wajib pajak akan semakin termotivasi dalam membayar PBB.

Pajak Penerangan Jalan (PPJ) adalah komponen terbesar ketiga dalam pajak daerah. Proporsinya turun sejak 2012 namun cenderung stabil selama beberapa tahun terakhir. Strategi yang dapat dilakukan untuk pptimalisasi PPJ dapat dilakukan melalui kerja sama dengan PLN, digitalisasi data, dan pengawasan yang lebih ketat.

\section{Penutup}

Kota Malang masih mengandalkan pajak sebagai sektor utama penopang PAD nya. Inovasi yang dilakukan sebagai konsekuensi hanya berorientasi pada pembaharuan sistem ekstensifikasi dan intensifikasi tanpa terlihat adanya komitmen secara serius untuk mengedepankan eksplorasi potensi beyond pajak. Dampaknya dapat terlihat ketika terjadi situasi krisis seperti pandemi covid 19, masing-masing wilayah terlihat kewalahan dalam menggenjot perekonomiannya dengan tetap melihat sektor pajak sebagai main safety net. Sehingga diversifikasi dan ekplorasi potensi diluar pajak perlu segera dilakukan.

Diperlukan optimalisasi sektor diluar pajak, tujuannya adalah agar jika sewaktuwaktu terdapat gap antara target dan realisasi pajak daerah mampu untuk memiliki sektor penopang alternatif yang sama kuatnya dengan sektor pajak. Ada beberapa alternatif yang bisa diupayakan, seperti mendorong pertumbuhan sektor UMKM yang disesuaikan dengan potensi daerah, kemudian pemerintah dapat melakukan kegiatan ekspor komoditas unggulan serta menggenjot performa BUMD potensial. 
Dalam pengelolaan pajak daerah, desentralisasi fiskal memang memberikan aturan yang kaku kepada pemerintah daerah dalam mengelola keuangan daerah. Walaupun demikian, pemerintah daerah sebenarnya masih dapat mengoptimalkan pendapatan asli daerah melalui optimalisasi pajak daerah. Optimalisasi pajak daerah ini harus dilakukan melalui analisa potensi daerah. Apabila hal ini telah dilakukan maka pemerintah kota akan dapat mengurangi ketergantungannya terhadap pemerintah pusat.

Pemerintah Kota Malang memiliki 9 jenis pajak daerah, yaitu pajak hotel, restoran, hiburan, reklame, PPJ, parkir, air tanah, BPHTB, dan PBB. Dari kesembilan jenis pajak daerah ini, BPHTB, PBB, dan PPJ adalah komponen terbesar penyumbang pajak daerah. Sayangnya ketiga jenis pajak ini selama 2012-2019 mengalami tren penurunan proporsi. Hal ini dikarenakan adanya kenaikan proporsi pajak oleh pajak hotel dan restoran.

Menurunnya tren proporsi BPHTB dan PBB diikuti dengan naiknya tren proporsi pajak hotel dan restoran menunjukkan adanya pertumbuhan yang bagus di sektor pariwisata. Pemerintah Kota Malang sebaiknya memanfaatkannya untuk optimalisasi pajak daerah. Pemerintah Kota Malang dapat mengeluarkan kebijakan untuk mendukung berkembangnya hotel dan restoran, sebagai contoh mempermudah perizinan, membuat bursa hotel dan restoran, melakukan pembinaan terhadap wisma pariwisata, rumah kos, maupun apartemen yang disewakan. Maraknya platform penginapan di Kota Malang juga perlu dilakukan pendataan untuk meningkatkan penerimaan dari jenis non-hotel.

\section{Ucapan Terima Kasih}

Terima kasih kepada Anisa Salsabila yang telah membantu mencarikan data di Badan Pelayanan Pajak Daerah dan BAPPEDA Kota Malang, Badan Pelayanan Pajak Daerah Kota Malang, BAPPEDA Kota Malang, dan Universitas Brawijaya.

\section{Pendanaan}

Penulisan artikel ini merupakan luaran atas penelitian atas pembiayaan dari dana DIPA Universitas Brawijaya

\section{Daftar Pustaka}

Ardiansyah, M. N. (2019). BP2D Kota Malang Kejar Target Pendapatan Daerah Sektor BPHTB. Retrieved November 8, 2020, from https://www.timesindonesia.co.id/ $\mathrm{read} /$ news/235917/bp2d-kota-malang-kejar-target-pendapatan-daerah-sektorbphtb

Creswell, J. W. (2014). Research Design: Pendekatan Kualitatif, Kuantitatif, dan Mixed. Yogyakarta: Pustaka Pelajar.

Gay, L.R., Mills, G.E. and Airasian, P. (2006). Educational research: Competencies foranalysis and application. New York: PrenticeHall. 
Horota, P., Ida, A., \& Purba, R. (2014). Peningkatan Pendapatan Asli Daerah dalam Rangka Otonomi Daerah melalui potensi pajak dan retribusi daerah di Kabupaten Jayapura. Keuda, 2(1), 1-33.

J.W. Creswell. (1994). Research design: Qualitative and quantitative approaches. Thousand Oaks, California 91320: SAGE Publications, In.

Kabul, L. T. A. (2020). 30 Ribu Mahasiswa di Malang akan Mendapatkan Bansos. Retrieved November 8, 2020, from https://www.ngopibareng.id/timeline/walikota-malang-akan-data-mahasiswa-di-malang-untuk-dapat-bansos-2645216

Kuncoro, H. (2004). Pengaruh Transfer Antar Pemerintah pada Kinerja Fiskal Pemerintah Daerah Kota dan Kabupaten di Indonesia. Jurnal Ekonomi Dan Pembangunan, (34), 47-63.

Liana, N. (2017). Optimalisasi peningkatan pendapatan asli daerah dihubungkan pariwisata kota bogor dan kabupaten bogor. Jurnal Living Law, 9(1), 103-115.

Lofland, L. H. (2006). From J. Lofland, D. Snow, L. Anderson \& L.H. Lofland (2006). Analyzing Social Settings: A Guide to Qualitative Observation and Analysis. (4th Ed.) Belmont, CA: Wadsworth Thomson. Analyzing Social Settings: A Guide to Qualitative Observation and Analysis (4th Ed.), 195-219.

Musgrave, Richard A., Musgrave, P. B. (1989). PUBLIC FINANCE IN THEORY AND PRACTICE (5th ed.). Singapore: McGraw-Hill Book Co.

Pandaya. (2016). In the Regions, Autonomy Simply Means Paying More Tax. Retrieved from https://www.thejakartapost.com/news/2016/03/28/in-regions-autonomysimply-means-paying-more tax.html

Ratri, N. (2019). Gerak Cepat Selamatkan Lingkungan, BP2D Kota Malang Sidak 21 Titik Pajak Air Tanah. Retrieved from http://malangtimes.com/baca/36025/ 20190213/102100/gerak-cepat-selamatkan-lingkungan-bp2d-kota-malang-sidak21-titik-pajak-air-tanah

Romi A.S, M. N., \& Larasati, D. C. (2018). Strategi Badan Pelayanan Pajak Daerah Kota Malang Dalam Mengurai Tunggakan Pajak Bumi Bangunan (Pbb). Reformasi, 8(2), 109. https://doi.org/10.33366/rfr.v8i2.1098

Safitra, N. (2019). Strategi Peningkatan Pendapatan Asli Daerah (PAD) Melalui Intensifikasi dan Ekstensifikasi Penerimaan Pajak dan Retribusi Daerah di Kabupaten Enrekang. JAKPP (Jurnal Analisis Kebijakan \& Pelayanan Publik), 37-48.

Samad, R. P., \& Iyan, R. Y. (2013). Analisis Potensi Pendapatan Asli Daerah Dan Dana Perimbangan Kabupaten Rokan Hilir. Jurnal Sosial Ekonomi Pembangunan, 3(8), 103-122.

Sukarelawati, E. (2019). DPRD Kota Malang soroti minimnya realisasi PAD pajak penerangan. Retrieved from https://jatim.antaranews.com/berita/325380/dprdkota-malang-soroti-minimnya-realisasi-pad-pajak-penerangan

Wardhono, A., Indrawati, Y., \& Qoriah, C. G. (2012). Kajian Pemetaan dan Optimalisasi Potensi Pajak dalam Rangka Meningkatkan Pendapatan Asli Daerah (PAD) Di 
R. Triarda \& R. Damayanti Analisis Optimalisasi Potensi Daerah untuk Meningkatkan Pendapatan Asli Daerah Kota Malang

Kabupaten Jember. J@Ti Undip: Jurnal Teknik Industri, 7(2), 69-76.

Worumi, H. (2018). Model Strategi Peningkatan Pendapatan Asli Daerah Kabupaten Sarmi Provinsi Papua. Jurnal Ekologi Birokrasi, 6(3), 23-39.

www.straitstimes.com. (2016). Malaysian Opposition Politician Rafizi Charged With

Criminal Defamation, OSA Offences. Retrieved from https://www.straitstimes.com/asia/se-asia/malaysian-opposition-politician-rafizicharged-with-criminal-defamation-osa-offences

Yustika, A. E. (2008). Desentralisasi Ekonomi di Indonesia Kajian Teoritis dan Realitas Empiris. Malang: Bayumedia.

\section{Tentang Penulis}

Reza Triarda adalah Dosen Program Studi Ilmu Hubungan Internasional, Jurusan Politik, Pemerintahan dan Hubungan Internasional, Fakultas IImu Sosial dan IImu Politik Universitas Brawijaya. Penulis memiliki ketertarikan penelitian dengan tema ekonomi politik.

Ratnaningsih Damayanti adalah Dosen Program Studi Ilmu Pemerintahan, Jurusan Politik, Pemerintahan dan Hubungan Internasional, Fakultas IImu Sosial dan IImu Politik Universitas Brawijaya. Penulis memiliki ketertarikan penelitian dengan tema ekonomi politik, otonomi daerah, dan local branding. 